\title{
Importance of male and ephippial female characters for differentiating three Palaearctic species of Macrothrix Baird, 1843 (Cladocera: Anomopoda), with a redescription of Macrothrix dadayi Behning, 1941
}

\author{
A.A. Kotov
}

A. N. Severtsov Institute of Ecology and Evolution, Leninsky Prospect 33, Moscow 119071, Russia. E-mail: alexey_kotov@sevin.ru

I examined ephippial females and males of the Palaearctic Macrothrix hirsuticornis Norman \& Brady, 1867 and M. tripectinata Weisig, 1934 (Cladocera: Anomopoda: Macrothricidae). Parthenogenetic and ephippial females, and males of a third species, M. dadayi Behning, 1941, are redescribed on material from the Ciscaucasian coast of the Black Sea (Russia). A series of male characters, useful for species discrimination was found. Ephippia of $M$. tripectinata and $M$. dadayi are covered with small spinules, a unique synapomorphy of these species. Recent progress in Macrothrix systematics allows us to predict that the taxonomy will improve as more males and ephippial females (currently known only in half the species), yet especially valuable for systematics, are described

Keywords: Cladocera, Macrothricidae, systematics, taxonomy, Palaearctic

\section{Introduction}

Two books of Smirnov $(1976,1992)$ were important steps in the study of Macrothrix Baird, 1843 - the most speciose and common genus of the family Macrothricidae Norman \& Brady, 1867 (Cladocera: Anomopoda). In the second book (Smirnov 1992), a series of previously described taxa were synonymised and the existence of a series of widely distributed groups was verified, i.e. $M$. hirsuticornis, spinosa, laticornis, triserialis, and others. Next, Silva-Briano et al. (1999) demonstrated that M.laticornis $\mathrm{s}$. lat. is a series of relatively locally distributed species, while Dumont et al (2002) found that populations of $M$. cf. triserialis from different continents also belong to a series of separate species.

The latest period in the systematics of Macrothrix, which started with the dissertation of Silva-Briano (1998), is characterized by a re-evaluation of characters used in species diagnoses. Some features, earlier regarded as diagnostic (e.g. presence of a tooth-like projection dorsally on the posterior border of the head, and expression of additional spines on segments of antenna II), now seem of limited significance (Silva-Briano 1998, Kotov etal.2004). Kotov (1999, 2007) concluded that the character "dilated antenna I" works only in cases of strong widening; describing this appendage as "slightly widened" or "not widened" is subjective. Use of this character in keys for identifying Macrothrix species has become largely irrelevant (Kotov 1999: 79).

In contrast, some "micro" characters, such as the armature of the labrum, setae and spines on antenna II, and parts of the thoracic limbs, have now become important in systematics (Silva-Briano 1998, Kotov 1999, 2007). Characters of sexual specimens are considered especially valuable for species demarcation in anomopod families (Goulden 1968, Smirnov 1971, Frey 1987, Kotov 1996, Kim et al. 2006). Unfortunately, males have only been described (often superficially) in about half of all known Macrothrix species (Smirnov 1992, Kotov 1999), although the situation is improving (Kotov et al. 2004, Garfias-Espejo et al. 2007).

Here, I aim to demonstrate the taxonomic importance of male and ephippial female characters in three Palaearctic species of Macrothrix viz. M. hirsuticornis Norman \& Brady, 1867; M.tripectinata Weisig, 1934 and M. dadayi Behning, 1941. At the same time, I present a redescription of the latter species, almost forgotten after its discovery. 


\section{Material and methods}

Animals were selected from formalin-preserved samples under a binocular stereoscopic microscope, placed on slides (in a drop of a glycerol-formaldehyde mixture) and studied under an optical microscope in toto. At least five parthenogenetic females, five ephippial females and five males from each locality were dissected under a stereoscopic microscope for the study of appendages and postabdomen. Drawings were prepared using a drawing apparatus attached to an Olympus CX41 microscope.

A standard system of numeration for setae on thoracic limbs, initially proposed by Kotov (2000) for chydorids, was used, on basis of the similarity of limbs in Chydoridae and Macrothricidae (Smirnov 1971, 1976). All operations with SEM were described previously (Kotov 1999, 2000). In case of $M$. hirsuticornis and M. tripectinata, only descriptions containing information on ephippial females and males are included to the synonymy.

\section{Results}

\section{Macrothrix hirsuticornis Norman \& Brady, 1867:} Figs 1A-B, 2.

Macrothrix hirsuticornis Norman \& Brady, 1867: 1011, Pl. 23: Figs 6-7; Berg 1933: 12-16, Figs 1-4; Manujlova 1964: 182-183, Fig. 78; Flössner 1972: 252256, Figs 119-120; Smirnov 1976: 79-87, Figs 49-50, 5253, 55-56 (only from Palaearctic!); Hudec 1983: 28-30, Figs 2-13; Negrea 1983: 209-215, Figs 84-86 (hirsuticornis and groenlandica); Margaritora 1985: 194-198, Figs 79-80; Smirnov 1992: 37-45, Figs 100, 106-129 (only from Palaearctic!); Alonso 1996: 241-242, Figs 17108; Silva-Briano 1998: 247-252, text-Figs 1-12, Figs 19-39; Flössner 2000: 65-68, Fig 24.

Not M. hirsuticornis in Gurney 1909: 290-291, Pl. 10: fig. 16; Pl. 11: figs 17-18.

Material examined: five ephippial females and ten adult males from a pool on Juist Island, East Frisian Islands, Lower Saxony, Germany, collected on June 26th of 1987 by W. Hollwedel.

\section{Redescription of gamogenetic specimens}

Ephippial female: Body ovoid, dorsal margin convex (Fig. 1A). Dorsal portion of valves forming an ephippium, slightly pigmented brownish, without clear border with rest of valves. Dorsal wall of carapace forms a chitinised plate. Surface of ephippium reticulated, central part of each cell depressed (Fig. 1B). One-three (normally two) eggs in ephippium.
Adult male: Body ovoid to subquadrangular (Fig. 2A) in lateral view, dorsal margin convex, with border between head and valves as a "step", postero-dorsal angle obtuse, rounded, above longitudinal body axis. Head with dorsal margin convex, no dome above eye; ventral margin straight, with small projection at base of antenna I, without ridges; a fold surrounds base of labrum (Fig. 2B), compound eye large, ocellus about half its size, located near tip of rostrum. Dorsal organ small. Labrum without projected apex and tubercles, with relatively large distal labral plate. Ventral margin with relatively long setae.

Postabdomen (Fig. 2C) ovoid, ventral margin undulated, lacking setules. Gonopores at a distance from base of postabdominal claw. Dorsal margin distinctly bilobed, preanal margin regularly convex, with short transversal series of minute setules. Anal margin with setules significantly larger than those on preanal margin; laterally to them a series of finer setules. No reticulation on sides of postabdomen (well-developed in female!). Postabdominal claws relatively short, regularly bent dorsally, with pointed tip (Fig. 2D). On claw, 5-7 fine external spinules; medial row of 4-5 denticles. Postabdominal seta remarkably longer than postabdomen, with distal and proximal segments subequal in length, proximal segment with few short setules, distal segment bilaterally armed with long setules.

Antenna I relatively thick, dilated distally (Fig. 2E-F); antennular sensory seta long, at about 2 antennular diameters (at base) from antenna I joint. On anterior surface of antenna I, somewhat distally to level of sensory seta, a large male seta, about half antenna Ilength, bisegmented, basal segment short and naked, distal segment fully setulated. About 6-7 transverse rows of spinules on anterior surface of antenna I, but no reticulation. Fourteen terminal aesthetascs (length of largest one about 0.2 antenna I length) of somewhat different length, tip of each aesthetasc with cavity. Antenna II larger than in female; distal burrowing spine longer than first exopod segment, a spine on second segment of exopod half as long as next segment, or longer. Limb I with outer distal lobe as in female, bearing long terminal seta with numerous setules distally, and small lateral seta (Fig. 2H); inner distal lobe with four setae, shortest one naked, additional male seta large, naked; copulatory hook large, with 3 ridges distally, copulatory brush seta on low pedestal.

Size: Ephippial females 0.5-0.65 mm, males 0.4-0.65 mm (Flössner 2000).

Comments: $M$. hirsuticornis was redescribed by Silva-Briano (1998), with some errors, indicated below. 

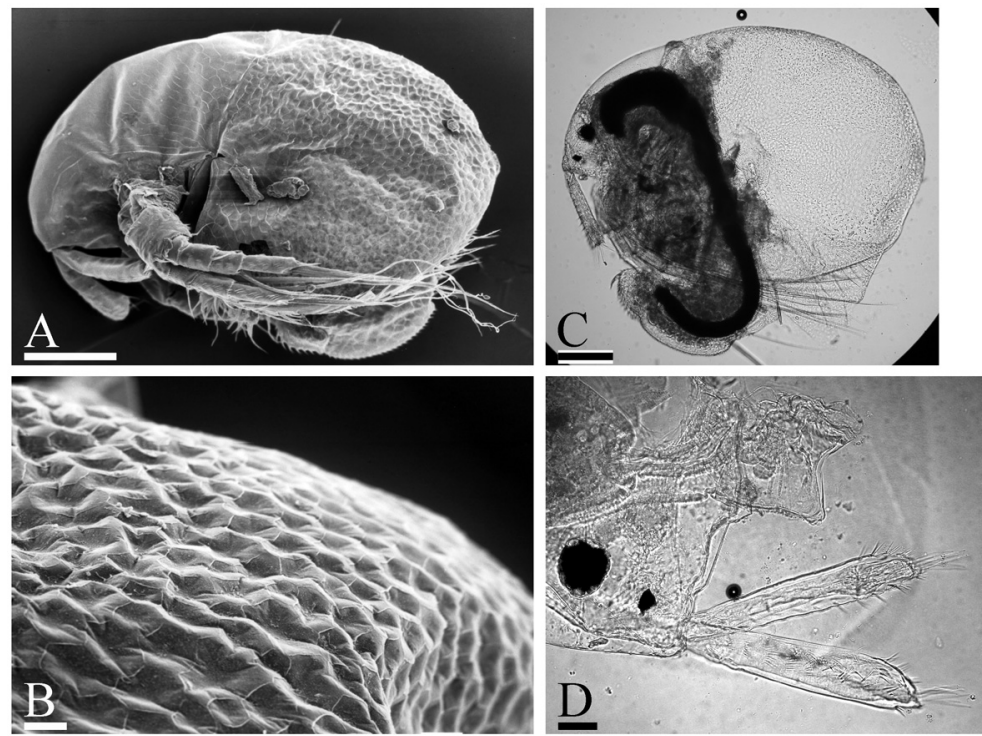

Fig. 1. Ephippial female of Macrothrix. M. hirsuticornis from Juist Island, Lower Saxony, Germany, general view (A) and sculpture of ephippium (B); M. tripectinata from a temporary freshwater body NE of Lake Zorkul, East Pamirs, Tajikistan, general view (C) and head (D). Scale bars $0.1 \mathrm{~mm}$ for A, C; $0.01 \mathrm{~mm}$ for B, D.

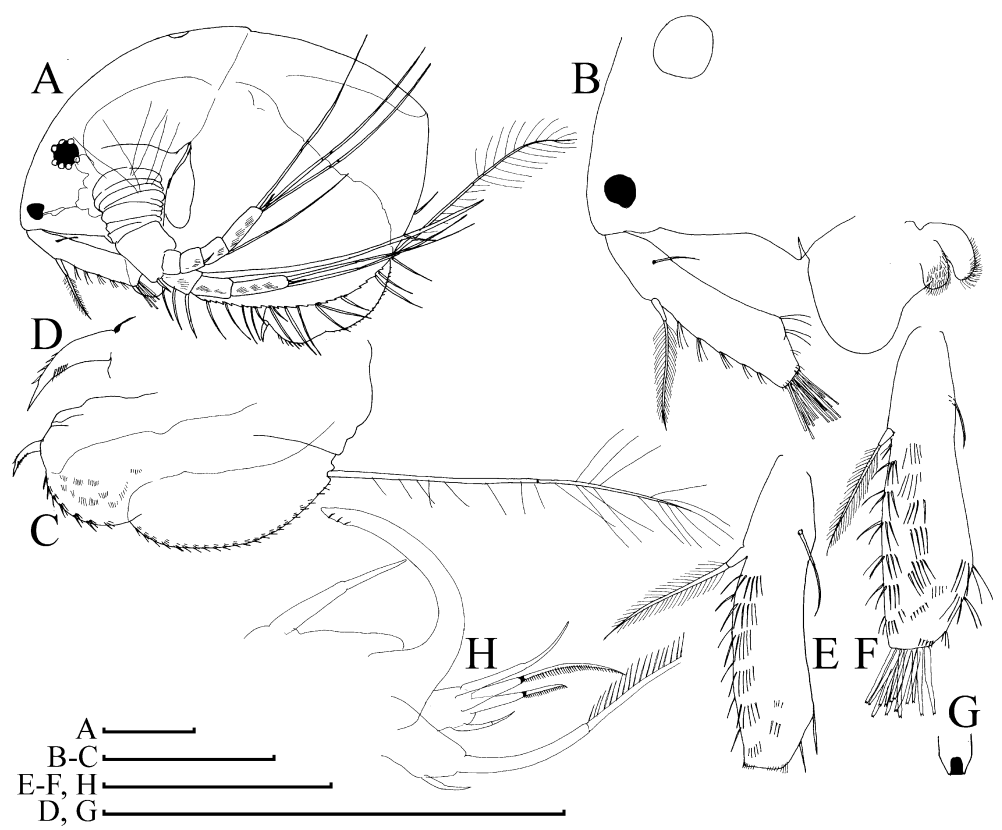

Fig. 2. Adult male of Macrothrix hirsuticornis from Juist Island, East Frisian Islands, Lower Saxony, Germany: general view (A); head (B); postabdomen (C); postabdominal claw (D); antenna I, lateral and anterior view (E-F); tip of aesthetasc (G); distal portion of limb I (H). Scale bars $0.1 \mathrm{~mm}$. 

3.

Macrothrix tripectinata Weisig, 1934: Figs 1C-D,

Macrothrixtripectinata Weisig, 1934: 87-90, Figs 1-7; Behning 1941: 223-225, Fig. 96; Manujlova 1964: 187189, Fig. 82; Smirnov 1976: 111-114, Figs 86-88 (Echinisca); Smirnov 1992: 62, 64-65, Figs 261-275; Kotov 1999: 64-76, Figs 1-110.

Material examined: parthenogenetic, ephippial females and males from pools at forest road near Gelendjik, Krasnodar Territory, Ciscaucasia, Russia, collected February 2004 by A. Y. Sinev. See other material in Kotov (1999).

Parthenogenetic female: armature of labral apex variable, from a single minute to 4 relatively large tubercles (Fig. 3A-E); postabdominal claw short, outer pecten spinulated (Fig. 3F); postabdominal seta with unilaterally setulated proximal segment and bilaterally setulated distal segment, size of setules on both segments approximately equal (Fig. 3G); antenna I "rod-like" to slightly widened distally (Figs 1C-D, 3H), nine terminal aeshetascs (Fig. 9I).

Ephippial female: Ephippium almost transparent (Fig. 1C), its surface covered with spinules (Fig. 3K).

Adult male: described by Kotov (1999), see also Fig. 3L-W here. Antenna bears 13-14 aesthetascs (not 9, erroneously indicated by me in 1999).

Comments: Kotov (1999) redescribed this species. Re-examination of one, as well as few additional samples, revealed that some details were described too superficially. Only these are discussed here.

\section{Macrothrix dadayi Behning, 1941: Figs 4-11.}

Macrothrix dadayi Behning, 1941: 219-220, Fig. 94; Manujlova 1964: 183-185, Fig. 79; Smirnov 1976: 91, Figs 62-63; Smirnov 1992: 23 (as Incerta sedis).

? Macrothrix spinosa King in Daday 1901: 447-448, Pl. 22: Figs 16-18, Pl. 23: Fig. 1.

? Macrothrix hirsuticornis Norman \& Brady in Gurney 1909: 290-291, Pl. 10: fig. 16; Pl. 11: figs 17-18.

Type material: lost.

Type locality: "shallow pools in the valley of the Rion River near Kutaisi" (Behning 1941), Georgia.

Material examined: parthenogenetic, ephippial females and males from pools near a forest road in the Shel Lobanova valley at Maliy Utrish, Novorossiysk Area, Krasnodar Territory, Ciscaucasia, Russia, May 15th 1995, leg. A. O. Bienkowski \& M. Ja. Orlova-Bienkowskaja.

\section{Full redescription}

Adult parthenogenetic female: Body subovoid in lateral view, maximum height in the middle, height/ length $=0.55-0.72$. Dorsal margin regularly arched from tip of rostrum to posteriormost point (Fig. 4A), without cervical depression, sometimes with slight depression at posterior boundary of head, (Fig. 5A). Dorsal margin of valves slightly elevated above dorsal margin of head. Postero-dorsal angle a rounded triangle, ventral to longitudinal body axis. No particular structures on valves or head. Body moderately compressed (Fig. 5B). Head large; in lateral view, its dorsal margin evenly convex, no dome above eye; ventral margin almost straight, without ridges, no projection at base of labrum (Fig. 4B). A special line (fold) runs from mandibular joint anteriorly, it corresponds to a poorly expressed fornix. Compound eye large, ocellus small (less than half of eye diameter), located approximately in the middle between tip of rostrum and eye or close to the latter. Frontal head pore a small transverse split somewhat dorsally to base of antenna I (Fig. 6A). "Dorsal head pore" (“dorsal organ") relatively large, ovoid, with thin ring (Fig. 5C). Labrum approximately triangular, with a projected apex, bearing small tubercles (Fig. 4B-E) and setulated distal plate. Valve surface with fine reticulation (Fig. 5A). Dorsal margin without serration, ventral margin denticulated. Marginal setae jointed to posterior sides of these denticles (Figs 4F-G, 5D). These setae variable in length and size in different individuals, but order of their sequence: two smaller setae between each bigger one, characteristic also many other species (Kotov 1999; Kotov et al., 2004). In anterior and posterior portion of ventral margin order of setal alternation not too accurate.

Thorax long, abdomen short, with large dorsal projection (Fig. 4H). Intestine without convolutions. Postabdomen subovoid in lateral view, with a rounded distal extremity, without "heel" basally. Ventral margin almost straight, with few series of setules. Dorsal margin distinctly bilobed; incision which bilobes the margin in lateral view in reality a depression at level of proximal border of anus (Figs 4H, 5D). Preanal margin long, regularly convex, with short transversal series of setules. On anal margin, groups of setules significantly larger than on postanal margin, laterally to them series of finer setules. Small postanal margin also with series of minute setules. Reticulation on sides of postabdomen present. Postabdominal claw long, regularly bent dorsally, with pointed tip. On claw, a series of 8-12 thin setules on external side, medial row (immediately on ventral margin as seen laterally) of about 6-10 denticles (Figs 4I, 5G), and inner dorsal row with numerous denticles, bigger in distal portion (Figs 4J, 5H). Postabdominal seta noticeably long 


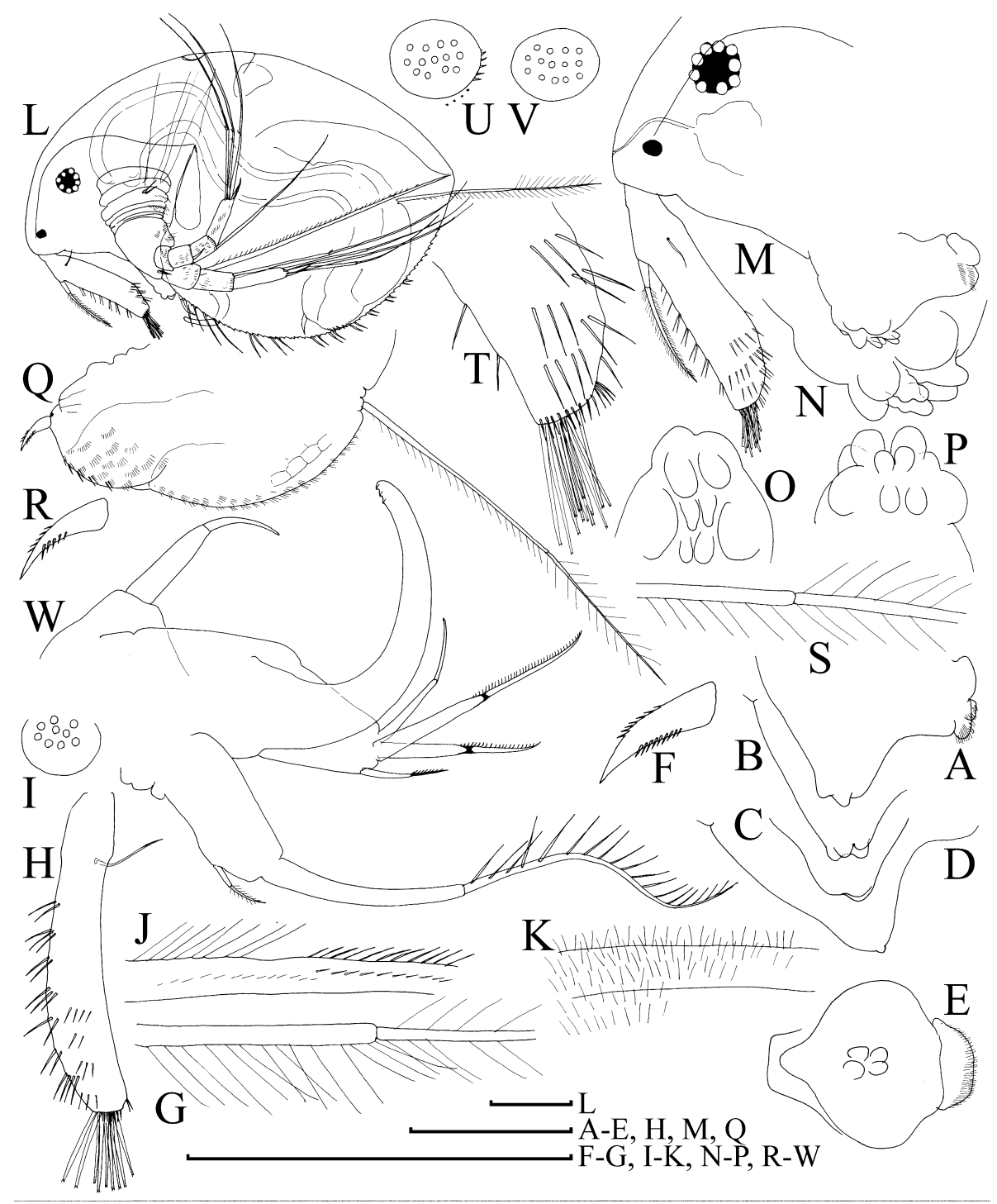

Fig. 3. Macrothrix tripectinata, parthenogenetic female (A-J), ephippium (K) and adult male (L-W) from a temporary freshwater body NE of Lake Zorkul, East Pamirs, Tajikistan: labrum in lateral view (A-D); its ventral view (E); postabdominal claw (F); postabdominal seta (G); antenna I (H); its distal end in distal view (I); seta on proximal segment of endopod of antenna II (J); sculpture of ephippium (K); adult male, lateral view (L); head (M); labrum in lateral, ventral and posterior view (N-P); postabdomen and postabdominal claw (Q-R); postabdominal seta $(\mathrm{S})$; end of antenna I (T); the same in distal view $(\mathrm{U}-\mathrm{V})$; distal portion of limb I (W). Scale bars $0.1 \mathrm{~mm}$.

than postabdomen, with proximal and distal segments subequal in size, proximal segment unilaterally armed with long setules; distal segment bilaterally with shorter setules (Fig. 4K).

Antenna I more or less widened distally, without subapical external angulation (Figs 4L, 6A); with sensory seta externally at distance of about two antennular diameters (at base) from antenna I joint, about 8-10 transverse rows of spinules on its inner face, few series of fine spinules at distal end. Nine relatively short terminal aesthetascs (longest less than 1/4 of antenna I length), each with two minute 'claws' at apex (Fig. 4N), on distal end of antenna I (Figs 4M, 6B). Antenna II (Fig. 6C-D) large, coxal region folded, with two small basal sensory setae of slightly different size in middle part and rows of small setules on each fold (Fig. 7A).Basal segment robust, bearing numerous transverse series of spinules, and long, bisegmented distal sensory seta at inner (posterior) margin 


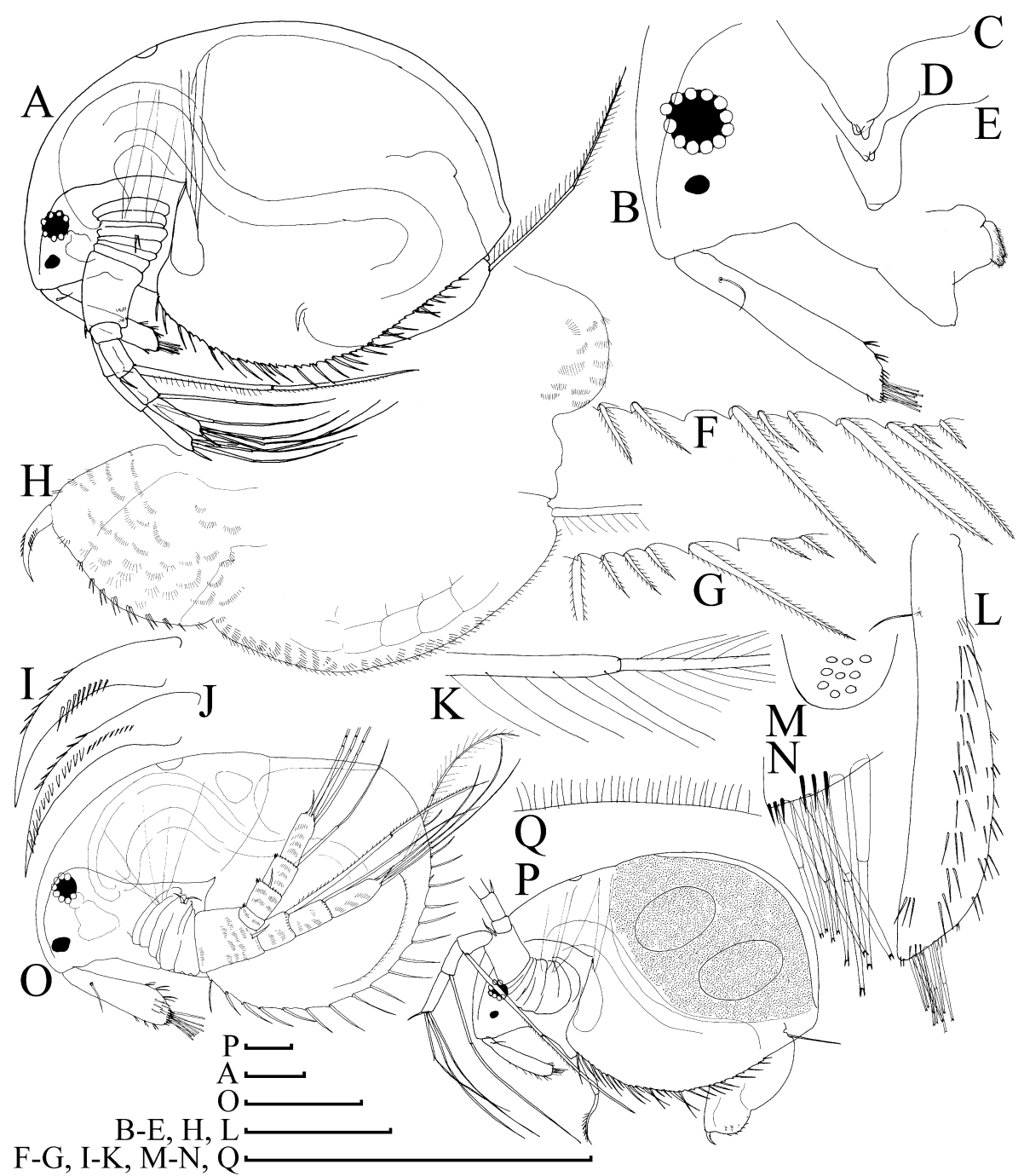

Fig. 4. Macrothrix dadayi, female from pools in the Shel Lobanova valley, Krasnodar Territory, Ciscaucasia, Russia: adult parthenogenetic female, lateral view (A); head (B); labrum (C-E); setae at middle and posterior portion of ventral margin (F-G); postabdomen $(\mathrm{H})$; postabdominal claw, outer and inner view (I-J); postabdominal seta (K); antenna I, anterior view (L); distal end of antenna I, distal and lateral view $(\mathrm{M}-\mathrm{N})$; juvenile female $(\mathrm{O})$; ephippial female $(\mathrm{P})$; sculpture of ephippium $(\mathrm{Q})$. Scale bars $0.1 \mathrm{~mm}$.

(Fig. 7B). Distal burrowing spine somewhat shorter than proximal segment of exopod, located on outer (anterior) surface, close to end of basal segment (Figs 6C-D, 7A). Antennal branches long (about two times longer than basal segment), only proximal member of exopod shortened, all other segments elongated, with transverse rows of fine setules (Figs 6C-D, 7A-D). Swimming setae 0-01-3/1-1-3, spines 0-1-0-1/0-0-1. Length of apical swimming setae subequal, approximately equal to length of basal segment plus length of branch. Each seta marked by individual number in Fig. 7A, armature of each seta illustrated in Figs 6E, 7E-H. Lateral seta on proximal endopod segment larger than other setae, lacking robust denticles in middle (Figs 6F, 7I-K). Apical spines relatively short (about third of apical segment length), slightly curved. A spine on second segment of exopod, as long as half of next segment. Short series of additional denticles on hind side of segments 1-3 of exopod.

Mandibles small, elongated, evenly dilated distally. Mandibular articulation at point where valves and head meet (Fig. 5A). Molar surface of right mandible in Fig. 8A-C, left mandible not studied under SEM.

Limb I large, without accessory seta; outer distal lobe cylindrical (Figs 6G, 9A-B); long apical seta with distal 

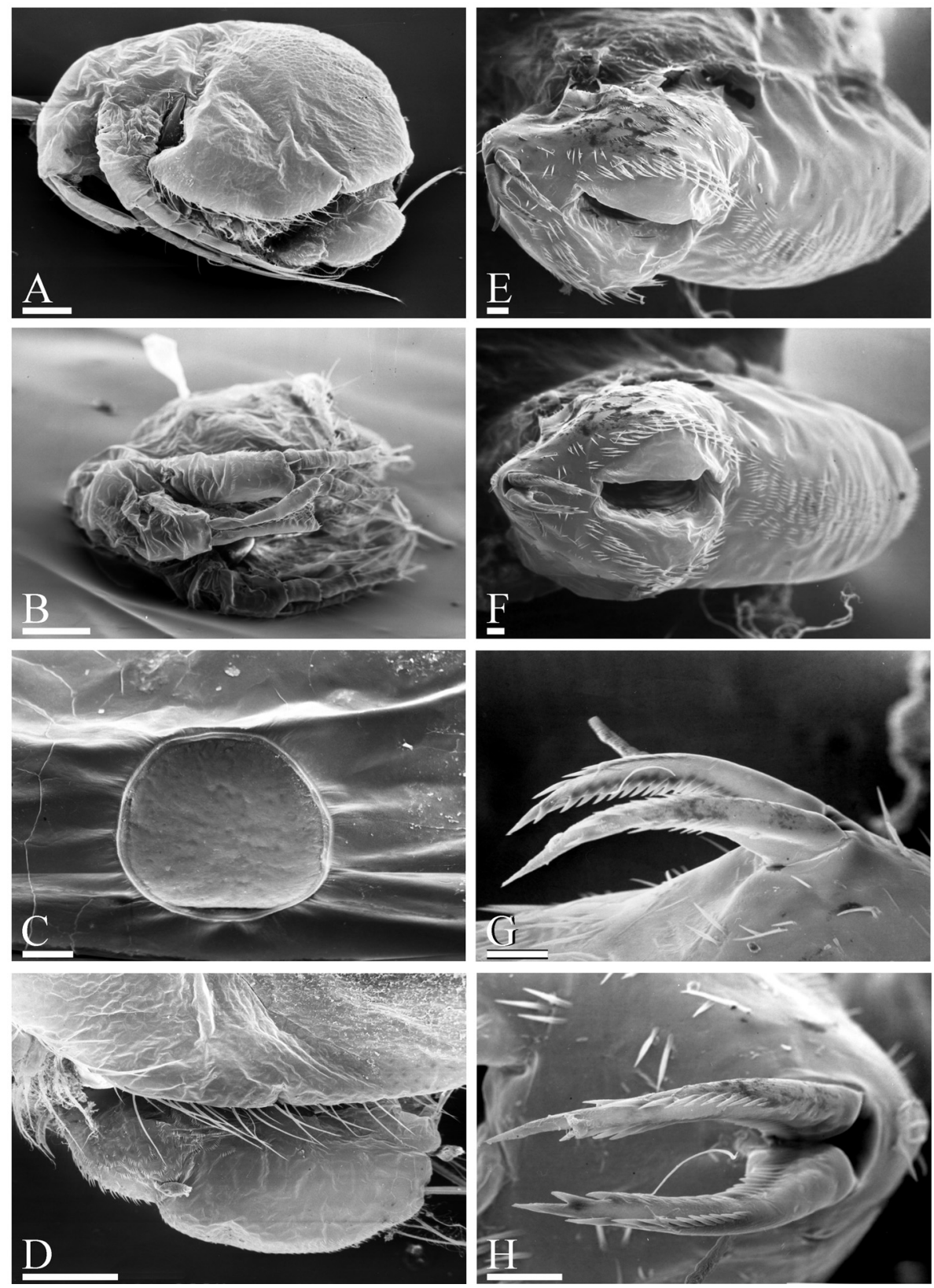

Fig. 5. Macrothrix dadayi, parthenogenetic female from pools in the Shel Lobanova valley, Krasnodar Territory, Ciscaucasia, Russia: lateral and anterior view (A-B); dorsal head pore (C); postabdomen (D-F); postabdominal claws, lateral and distal view (G-H). Scale bars $0.1 \mathrm{~mm}$ for A$\mathrm{B}, \mathrm{D} ; 0.01 \mathrm{~mm}$ for $\mathrm{C}, \mathrm{E}-\mathrm{H}$.

segment unilaterally armed with relatively robust setules, and small lateral seta. Inner distal lobe massive, with three series of setules, and three bisegmented setae of different size, unilaterally setulated in distal part, smallest one with numerous setules distally. Endite III with slightly curved, setulated seta (Fig. 9A: a), and straight setae b-c short; anteriorly on this endite a short, setulated, bisegmented seta 1. Endite II with three long bisegmented setae of subequal size (Fig. 9A: d-f), each with distal segment bearing fine setules distally and robust setules basally, and with fully setulated basal segment and forked seta 2 (Figs 6H, 9C) anteriorly. Endite I 

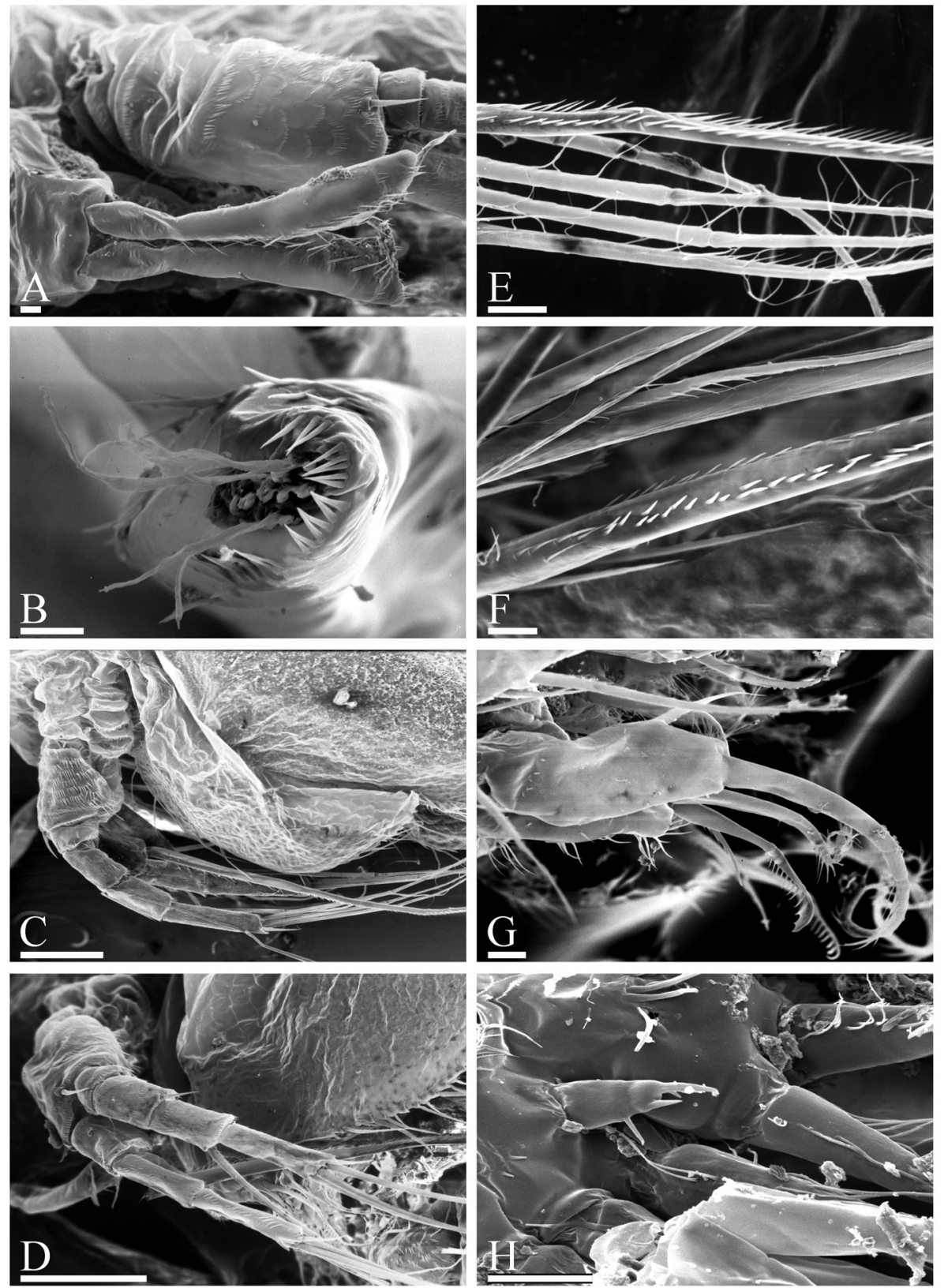

Fig. 6. Macrothrix dadayi, parthenogenetic female from pools in the Shel Lobanova valley, Krasnodar Territory, Ciscaucasia, Russia: rostrum and antennae I (A); end of antenna I (B); antenna II (C-D); setae of antenna II (E-F); distal portion of limb II (G); seta 3 (H ). Scale bars 0.1 $\mathrm{mm}$ for A-B, D-h; $0.01 \mathrm{~mm}$ for C.

with two bisegmented setae (Fig. 9A: g-h) naked basally and supplied with long, dense setules distally; a fork-like seta 3 (Fig. 9D) anteriorly. Ejector hooks of different size; a fully setulated seta at inner side of limb base, socalled maxillar process, remainder of gnathobase I (Kotov 1999).
Limb II: Epipodite subglobular, exopodite a subovoid lobe with two transverse rows of small setules and short seta distally (Fig. 9E). At inner margin of limb, eight robust scrapers, scrapers 1-2 with delicate feathering, 3-8 with massive denticles, and small sensillum near scraper 1. Posteriorly to scrapers, a system of low hill- 


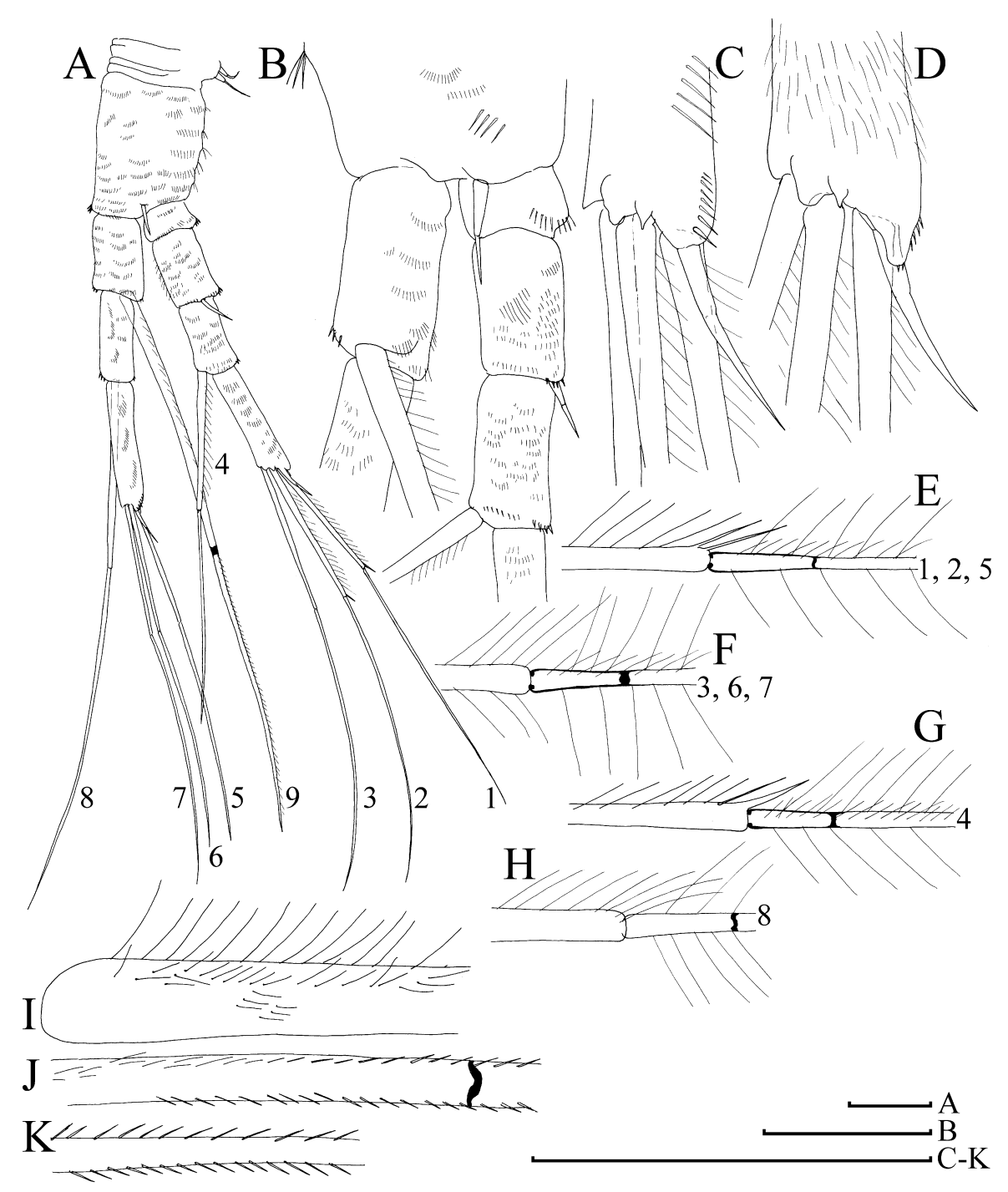

Fig. 7. Macrothrix dadayi, antenna II of parthenogenetic female from pools in the Shel Lobanova valley, Krasnodar Territory, Ciscaucasia, Russia: antenna II, anterior view (A); posterior view (B); apical segment of endopod (C); apical segment of exopod (D); apical setae (E-G); seta on second endopod segment $(\mathrm{H})$; proximal, medium and distal portion of seta on first (proximal) segment of endopod (I-K). Scale bars $0.1 \mathrm{~mm}$.

ocks, one near seta 4, and a solitary "soft" seta near gnathobase (Fig. 9F). Distal armature of gnathobase with four setae; filter with four long setae.

Limb III: Epipodite small, globular, exopodite large and flat, with three distal setae (Fig. 9G: 1-3), seta 1 shortest, with short, robust setule; setae 2-3 with long, fine setules, and setulated projections proximally to seta 3 and between setae 2 and 3 (Fig. 9H); lateral group consists of two setae (4 and 5), similar in armature with 2 and 3. Distal endite (see discussion of its homology in Kotov 1999) anteriorly with three bisegmented setae (Fig. 9I: 1-3), unilaterally armed in distal part, seta 1 with short denti- cles; small sensillum near each base of seta 1 and 3. Posteriorly, three soft setae: seta a with fine setules basally and robust spinules distally, setae $b$ and $c$ with fine setules distally, seta c shortest. Basal endite approximately equal in size to distal one. Anteriorly, a bottle-shaped sensillum and 4 setae with size increasing basally (Fig. 9G: 4-7), each with a tuft of distal setules. Posteriorly, 4 thick, soft setae $(\mathrm{d}-\mathrm{g})$ subequal in size, each armed with a tuft of setules, inflated basal portion and blunt tip. Gnathobase unclearly demarcated from basal endite, with large, bottle-shaped sensillum near border with basal endite, and two hooks distally. 

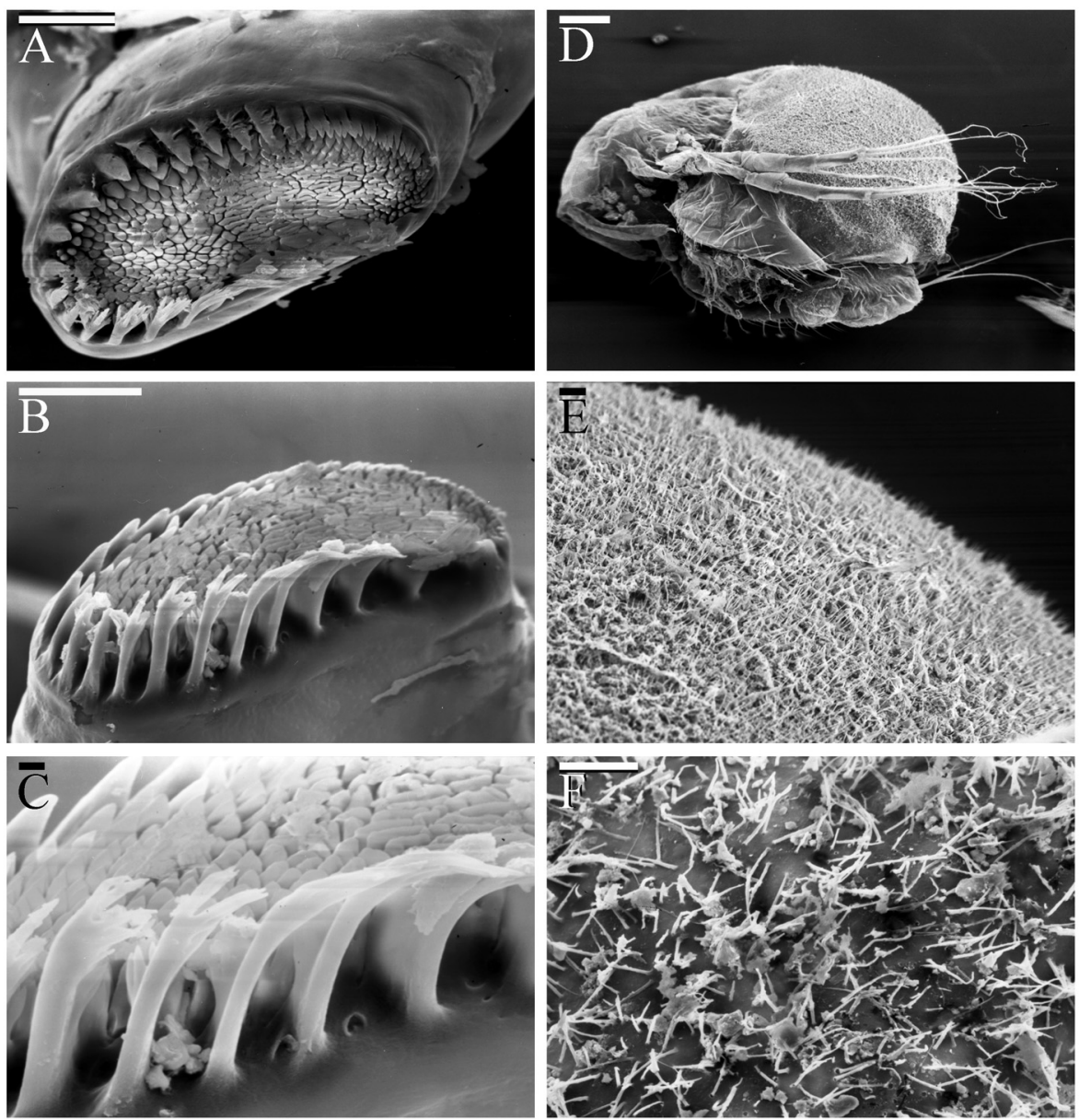

Fig. 8. Macrothrix dadayi from pools in the Shel Lobanova valley, Krasnodar Territory, Ciscaucasia, Russia: molar surface of right mandible, distal and inner-ventral view (A-B); teeth at ventral side (C); ephippial female (D); sculpture of ephippium (E-F). Scale bars 0.1 mm.

Limb IV: epipodite small and globular, exopodite small, with distal group of three bilaterally feathered setae of different size (Fig. 9J). Inner margin of limb with 4 setae, seta 1 with fine setules basally and distally, setae 2-4 with inflated basal and elongated distal part, the latter pointed at tip, fully feathered. A small sensillum near each base of seta 2 and 3. Posteriorly, a row of five long, soft setae, similar in size, bilaterally setulated from base to tip (Fig. 9J: a-e). Distal armature of gnathobase with 4 elements: a thick, bottle-shaped sensillum near border with basal endite; a large setae with inflated basal segment and elongated, fully setulated distal segment; a heavy hook; and a small, naked, bisegmented and curved seta. Posteriorly on gnathobase, a single small seta continues the posterior row of setae of the inner limb face, the sole remainder of filter plate IV.
Limb V: Pre-epipodite relatively large, tri-lobed; epipodite large, subglobular (Fig. 9K). A small lobe with single seta remains of the exopodite. Inner-distal portion a large flap, fringed by fine setules, on inner margin three setae with size increasing distally (Fig. 9K: 1-3).

Juvenile female: In contrast to adult, body somewhat lower (height/length $=0.57-0.65)$, subquadrangular, with more distinct posterior border of head, valve dorsal margin straight, postero-ventral angle oblique, located above middle axis of body (at level of dorsum), antennae II longer than in adult.

Ephippial female: In contrast to adult parthenogenetic female, body less high (height/length $=0.65-0.73$ ), dorsal margin more convex (Figs 4P, 8D). Dorsal portion of valves forming an ephippium, slightly brownish, without 


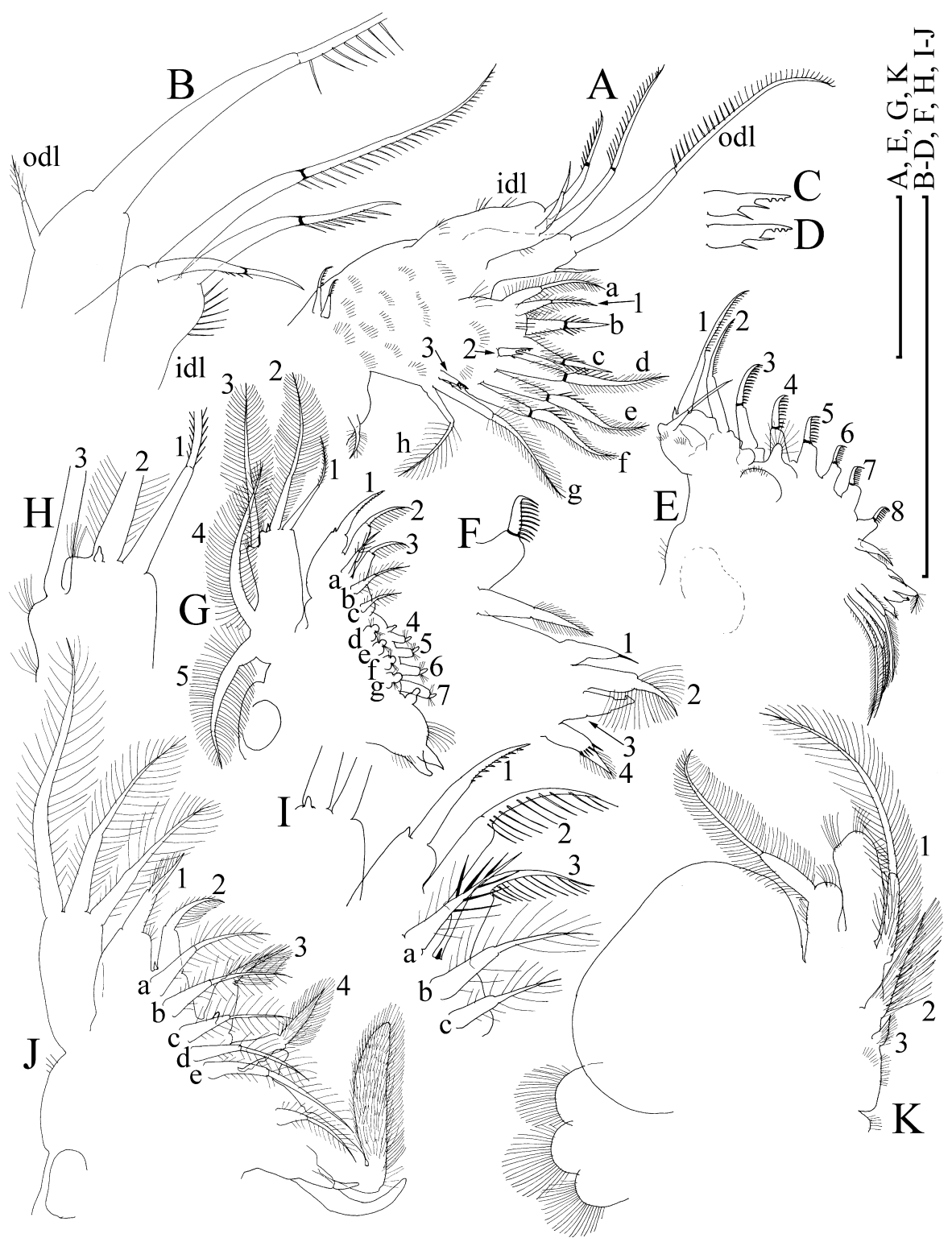

Fig. 9. Macrothrix dadayi, from pools in the Shel Lobanova valley, Krasnodar Territory, Ciscaucasia, Russia: limb I (A); its distal portion (B); anterior setae 2 and 3 (C-D); limb II and its inner portion (E-F); limb III, its exopodite and inner-distal portion (G-I); limb IV (J); limb V (K). Scale bars $0.1 \mathrm{~mm}$.

clear border with valves. Dorsal wall of carapace forming a chitinised plate. Surface covered with spinules (Figs 4P, 8E-F). One-three (normally two) eggs in ephippium.

Adult male: Body ovoid (Fig. 11A) to rhomboid (Fig. 10A) in lateral view, height/length $=0.58-0.64$, dorsal margin convex, sometimes almost straight in posterior portion of valves, postero-dorsal angle obtuse, rounded, approximately in longitudinal body axis. In anterior view, body somewhat compressed (Fig. 11B-C) as in female. Head with dorsal margin convex, no dome above eye; ventral margin straight, without ridges, no projection at base of labrum (Fig. 10B), compound eye large, ocellus about half its size, located in middle between compound eye and tip of rostrum. Dorsal organ small. Labrum with moderately projected apex bearing a system of tubercles (Figs 10B-D, 11D), and small distal 


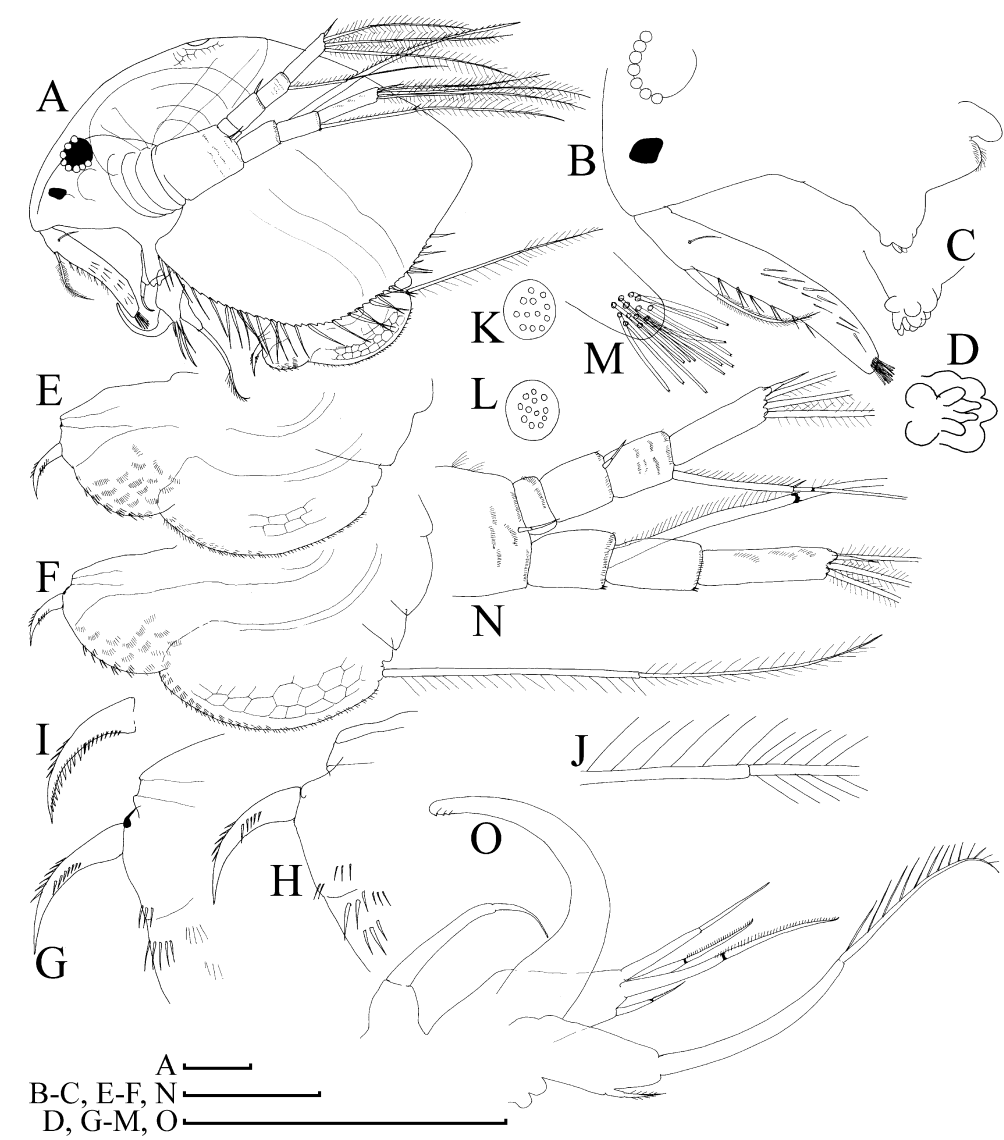

Fig. 10. Macrothrix dadayi, male from pools in the Shel Lobanova valley, Krasnodar Territory, Ciscaucasia, Russia: general view (A); head (B); labrum laterally and ventrally $(\mathrm{C}-\mathrm{D})$; postabdomen $(\mathrm{E}-\mathrm{F})$; its distal portion $(\mathrm{G}-\mathrm{H})$; postabdominal claw in inner view (I); postabdominal seta $(\mathrm{J})$; antenna I in distal view (K-M); antenna II (N); limb I, distal portion $(\mathrm{O})$. Scale bars $0.1 \mathrm{~mm}$.

labral plate. Valve surface with delicate reticulation, ventral margin as in female, but marginal setae longer.

Postabdomen (Figs 10E-F, 11E) similar to that in female, but with thicker distal portion, ventral margin straight, lacking any setules. Gonopores open subdistally, "under" (ventrally) to postabdominal claws. Dorsal margin distinctly bi-lobed, preanal margin regularly regularly convex, with short transversal series of minute setules. On anal margin groups of setules larger than those on preanal margin, laterally to them series of finer setules. A distinct reticulation on sides of postabdomen. Postabdominal claw long and thin, regularly bent dorsally, with pointed tip (Figs 10G-H, 11F). On claw, a series of 5-8 fine spinules on external side; medial row with about 5-7 denticles; on inner side (Figs 10I, 11F), a row of denticles, bigger in distal half. Postabdominal seta remarkably longer than postabdomen, with distal and proximal segments subequal in length, proximal seg- ment unilaterally armed with long setules, distal segment bilaterally armed with somewhat shorter setules.

Antenna I elongated, relatively thin, slightly S-shaped (Fig. 10B); antennular sensory seta small, located at about 1.5-2 antennular diameters (at base) from antenna I joint. On anterior surface of antenna I, somewhat distally to level of sensory seta, a large male seta (Figs 11CD), longer than half of antenna I length, bisegmented, with basal segment short and naked, and distal segment fully setulated. About 6-9 transverse rows of spinules on anterior surface of antenna I, but no reticulation. Twelvethirteen (Figs 10K-M) short terminal aesthetascs (length of largest one only about 0.1-0.15 antenna I length) of different length. Antenna II (Fig. 10N) with relative size larger than in female; distal burrowing spine on basal segment longer than in female, spine on second segment of exopod as in female. Limb I with outer distal lobe as in female (Fig. 10O); inner distal lobe with four setae, set- 

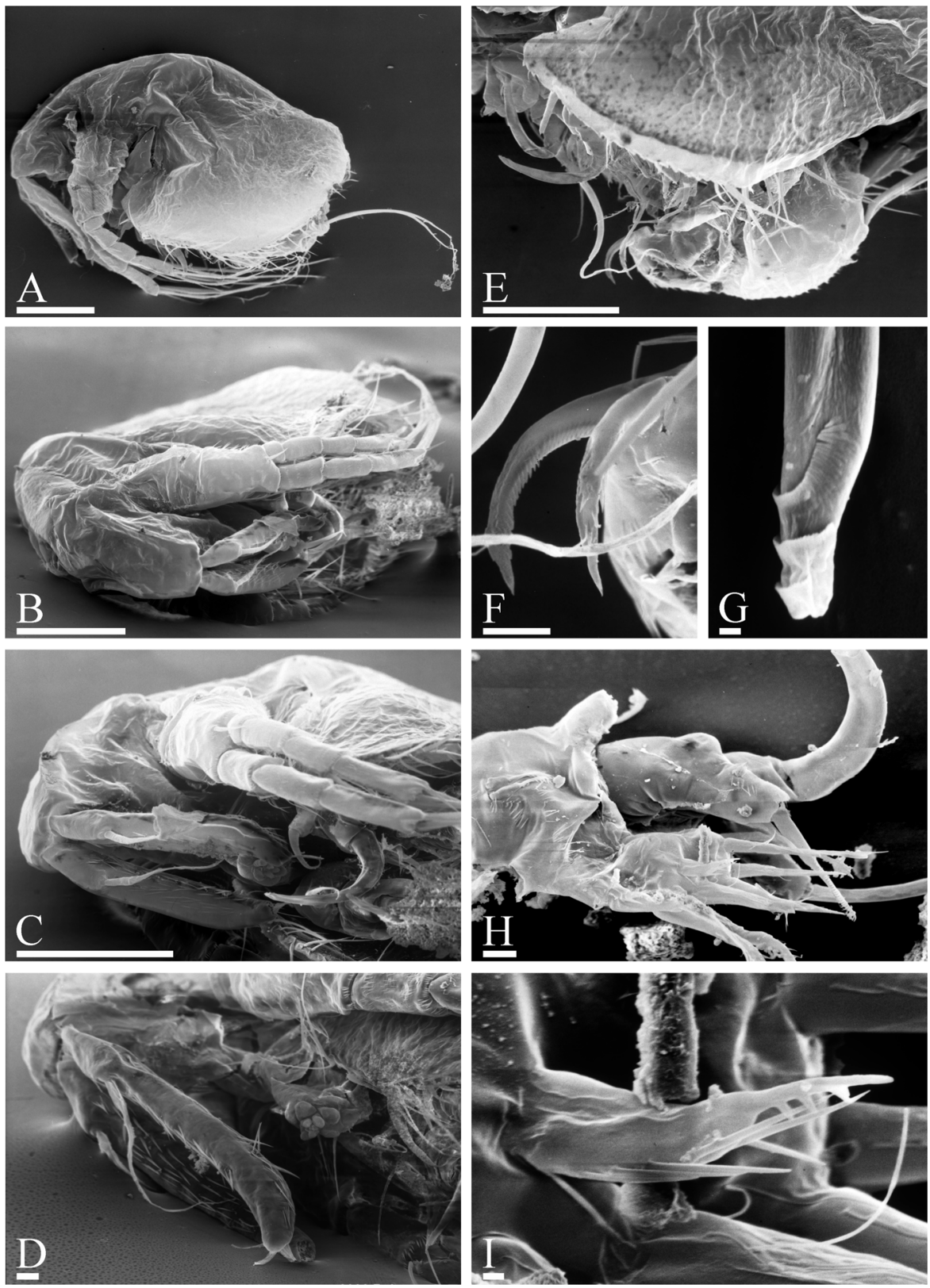

Fig. 11. Macrothrix dadayi, male from pools in the Shel Lobanova valley, Krasnodar Territory, Ciscaucasia, Russia: lateral and anterior view (AB); head (C-D); ventral body portion (E); postabdominal claws (F); tip of copulatory hook on limb I (G); limb I, inner view (H); anterior seta 3 (I). Scale bars $0.1 \mathrm{~mm}$ for A-C, E; $0.01 \mathrm{~mm}$ for D, F, H; $0.001 \mathrm{~mm}$ for G, I.

ulation of three setae homologous to those in female finer, fourth additional male seta large, naked; copulatory hook large, with 3 ridges distally (Fig. 11G), copulatory brush seta on a projected pedestal (Fig. 11H), bisegmented, with thin distal segment. Anterior setae 23 more thinner than in female (Fig. 11I).
Size: Parthenogenetic female 0.51-1.45 mm, ephippial females 0.76-1.00 mm, adult males 0.59-0.72.

Comments: In 1934-1940, Behning (1890-1943) made a series of collecting expeditions, aimed at preparing a revision of the Cladocera of USSR, and published a monograph on the Cladocerans of the Caucasus (Beh- 
ning 1941). The revision was never finished, because the author, an ethnic German, was arrested at the start of the war between Germany and the Soviet Union and died in a prison hospital in 1943.

M. dadayi Behning, 1941 was described from pools near Kutaisi, Georgia (a republic of the Soviet Union at that time). Below I offer an English translation of the description (Behning 1941: 219-220), quite detailed for its time, with my explanations in brackets:

"Female. Rather large species, with slightly convex dorsal margin. Postero-dorsal angle approximately in medium position on posterior margin of valve; smoothed-rounded or slightly prominent posteriorly. Depression between head and rest of body completely absent, sucker [= dorsal head pore] large, located on dorsal margin in posterior part of head. Rostrum bluntly pointed. Lateral head fold passes from tip of rostrum to posterior head edge above compound eye. Ventral head margin concave, with projection in posterior part. A double row of robust setae and denticles along whole dorsal margin of valves. Reticulation ill-defined.

Compound eye large (about 52-60 $\mu \mathrm{m}$ ). Ocellus (about $20 \mu \mathrm{m}$ ) located approximately in the middle between eye and base of antenna I. The latter slightly bent toward posterior direction, strongly dilated distally (about 180-240 $\mathrm{m} \mu$ in length). There are 6-7 incisions along anterior margin, with bunches of small setules, distally these rows of setules occupy the whole surface of antenna I. Two-three incisions with bunches of setules on posterior margin of antenna I distally. Distal end of antenna I truncated, with row of denticles, laterally to the latter there are small setules. Aesthetascs of more or less similar length, located in middle of distal end of antenna I. Sensory seta small, located near base of antenna I. Antenna II of moderate length, with two sensory setae on distal edge of its basis [=distal sensory seta plus distal burrowing spine], and several rows of small setules on its margin and its surface. Segments of both branches covered with rows of small denticles along their distal margins. Spines present on distal segments of both branches, and on second segment of exopod. Setae of the first endopod segment, and the third exopod segment particularly large, and (predominantly) unilaterally setulated.

Abdominal projections not found. Postabdomen relatively narrow, of grace shape; dorsal margin convex, with slight incision distally to its middle (near posterior margin of anus). Postabdominal setae long (about 520-570 $\mu \mathrm{m})$, with more or less equal distal and basal segments, setulated marginally. A row of denticles along preanal margin of postabdomen; rows of small setules laterally on sides in basal portion of postabdomen. Postanal mar- gin slightly convex, with 8-9 bunches of setules and several minute denticles between those and claw base. Postabdominal claws short (about 40-50 $\mu \mathrm{m}$ ), transparent, with two rows of small setules. Ventral margin of postabdomen with 4-6 setules at claw base. Length 0.85-1.27 mm. Male and ephippium unknown".

Some details, important for Macrothrix systematics, were not adequate in this first description. In his key, Behning (1941: 210-211) separated $M$. dadayi Behning, 1941 and M. hirsuticornis based on "claws with two rows of small setules" in the former and "smooth claws" in the latter, but this difference is an illusion. Subsequently, differentiation of $M$. dadayi from $M$. hirsuticornis was based on the difference in aesthetasc size (Smirnov 1976). Smirnov (1992) ranked $M$ dadayi as incertae sedis, but my re-examination of Caucasian samples resulted in confirmation of the validity of Behning's taxon.

Behning (1941) said that his taxon was earlier determined as M. spinosa by Daday (1902). Unfortunately, Daday's slide DAD II/P-419 containing two females from Mongolia dried out, and no other material is available (Smirnov 1992).

Differential diagnosis: $M$. dadayi is a close relative of $M$. tripectinata. Females of the two species differ from other Macothrix by having (1) small aesthetascs of subequal size, (2) an ephippium covered with small spinules and, (3) series of tubercles on labral apex. The main difference of $M$. dadayi with $M$. tripectinata is a thin (for the genus!) postabdominal claw (see also Table 1).

Distribution and biology: To date, $M$. dadayi is known only from the Caucasian region (Krasnodar Territory of Russia and Georgia); its real range is unclear. Behning's (1941) reference to Daday's (1901) "M. spinosa" from region of Aral Sea, Mongolia and China as $M$. dadayi needs confirmation. Records by Ibrasheva \& Smirnova (1983) from Kazakhstan and Kownacki et al. (1976) from Afghanistan must be also confirmed, because their descriptions were not accurate. Any populations, previously determined as $M$. dadayi, may belong to $M$. tripectinata, because the character earlier suggested to be helpful - antenna I widened distally or not is subjective (Kotov 1999).

Gurney (1909) illustrated a male of "M. hirsuticornis" from Tunisia with a long and thin postabdominal claw and a thin antenna II bearing small aesthetascs. He (1909: 291) said that "the surface [of ephippium] ... appears to be very dirty", which may reflect the presence of spinules. These Tunisian populations may belong to M. dadayi, which may therefore be a possible circum-Mediterranean species. 
Table 1. Differences between gamogenetic specimens of M. hirsuticornis, M. tripectinata and M. dadayi.

\begin{tabular}{lccc}
\hline Character & M. hirsuticornis & M. tripectinata & M. dadayi \\
\hline Ephippial female: & & & \\
Size, mm & $0.5-0.65$ & $0.75-0.95$ & $0.76-1.00$ \\
Ephippium surface covered with spinules & - & + & + \\
Adult male: & + & - & - \\
Body shape subquadrangular & - & + & + \\
Labrum with well-defined tubercles & - & - & + \\
Postabdomen with reticulation on sides & - & - & - \\
Postabdominal claw long & + & - & - \\
Proximal segment of postabdominal seta with rare & & - & + \\
setules & + & - & + \\
Distal segment of postabdominal seta with long setules & - & $13-14$ & $12-13$ \\
Antenna I very thin & - & - & + \\
Sensory seta specially small & 14 & + & + \\
Number of aesthetascs & - & - & + \\
Aesthetascs small & - & up to 0.6 & $0.59-0.72$ \\
Tip of copulatory hook blunt & - & + \\
Pedestal of copulatory brush seta strongly projected & $0.4-0.65$ & & + \\
Adult male size, mm & & & + \\
\hline
\end{tabular}

Behning (1941: 220) said that M. dadayi "occurs sporadically in shallow, temporary, sometimes very small waters without vegetation". Most probably, $M$. dadayi is relatively rare, with its rarity a reflection of life in temporary waters.

\section{Discussion}

The ephippium is a characteristic trait of the order Anomopoda. Its morphology differs between families (Dumont \& Negrea 2002, Kotov 2006b). In Macrothrix, the ephippium varyies between species. That of M. hirsuticornis (Berg 1933, Makrushin 1985), is modified as compared with its ancestral state, where differences between parthenogenetic and ephippial females were minimal (Kotov 2006b). Macrothrix capensis has an ephippium with a thick layer of porous chitin immediately under the external cuticle (Makrushin 1991). The M. laticornis or M. triserialis groups (Silva-Briano et al. 1999, Dumont et al. 2002, Kotov et al. 2004), have ephippia with rounded projections. Their existence probably reflects the presence of air chambers between the external and internal walls.
The ephippia of M. tripectinata and M. dadayi, covered in small spinules, are unique for the genus. These two species are apparently closest relatives, and their most obvious synapomorphy is the ephippium. The latter has three possible functions: (1) protective; (2) camouflage for the ephippial female; (3) dispersal, by attaching to the feathers of birds or hairs of mammals. Spinules on the valve surface are characteristic for parthenogenetic females of Macrothrix hystrix, Cactus cactus, and Neothrix sp. (Smirnov 1976, Kotov 2006a). Parthenogenetic females of Ceriodaphnia and Scapholeberis may also be spinulated, but not as densely as in the aforementioned, macrothricid-like genera.

In contrast, ephippia fully covered with spines were not described in anomopods previously. In some Daphnia, a dorsal plate of ephippium, where two valves joint together, is supplied with numerous small spinules (Glagolev 1983). Apparently, spinulation of the ephippium evolved independently in daphnids and macrothricids.

M. dadayi and M. tripectinata differ from M. hirsuticornis in a larger ephippial female, another synapomorphy of these two species. At the same time, size of adult 
males is similar in M.tripectinata and M. hirsuticornis, and larger in $M$. dadayi (Table 1). Absence of a correlation between size of ephippial female and male is surprising. May be, this difference (as well as strong differences in ephippium sculpture and "fine" differences in male characters), is connected with differences in male activity during copulation, which is complicated in anomopods (Smirnov 1971, Van Damme \& Dumont 2006), but so far unstudied in Macrothrix.

Differences between the males of three species of Macrothrix are listed in Table 1. Several previous authors presented descriptions and illustrations of $M$. hirsuticornis males (see list of synonymy in the hirsuticornis-section) (Alonso 1996, Silva-Briano 1998). But even in the most accurate descriptions, details important for systematics are lacking, and my own publication (Kotov 1999) is no exception. Only now, some ideas on differentiation of close, hirsuticornis-like species based on male characters can be proposed (Table 1). These differences are "micro-scale", and were missed by previous authors. Also, some mistakes were made, e.g. Silva-Briano (1998) found only a single sensory seta on antenna I of his M. hirsuticornis; probably, a large additional male seta had been lost during dissection.

Contemporary papers on Macrothrix (Silva-Briano 1998, Silva-Briano et al. 1999, Dumont et al. 2002) also do not describe the male labrum adequately, so tubercles on its apex are unknown. Yet, a complex system of hillocks on the male labral apex seems peculiar of hirsuticornis-like species (but not characteristic of hirsuticornis s. str.!). It is necessary to note that sexual differences in labrum morphology have not been recorded for other genera of Anomopoda either. Probably, these tubercles are sensory structures, although I did not see pores on their surface.

In some Macrothrix of the rosea-triserialis group, the distal part of male postabdomen looks like a tube with strongly or completely reduced postabdominal claws. In contrast, $M$. hirsuticornis-like species are characterized by a male postabdomen similar to that of the female. Thus, an important diagnostic character of $M$. daday female, a conspicuously thin postabdominal claw, is also characteristic of its male.

Antenna I in adult male of Macrothrix is markedly modified, and is normally elongated. Two Palaearctic congeners, $M$. dadayi and $M$. tripectinata, differ in length of male antenna I, like Mexican M. smirnovi and $M$. agsensis (Garfias-Espejo et al. 2007). This character seems of universal significance within Macrothrix.

In all anomopods, female antenna I bears nine aesthetascs, as in the majority of non-anomopod cladocer- ans (Korovchinsky 2004). Males usually also have nine aesthetascs. In contrast, males of some Aloninae (family Chydoridae Stebbing, 1902 sensu Dumont \& SilvaBriano 1998) have 12 aesthetascs, and in Eurycercus (family Eurycercidae Kurz, 1875 sensu Dumont \& SilvaBriano 1998) males have nine terminal and numerous lateral aesthetascs along the posterior side of antenna I (Smirnov 1971, Frey 1975). In some Macrothrix, the male antenna I bears nine aesthetascs (Dumont et al. 2002, Kotov et al. 2004). In contrast, it has 12-14 aesthetascs in $M$. hirsuticornis and its congeners. This may be a plesiomorphic state, or a secondary modification (polymerisation), or even a recapitulation of an ancestral state.

Gamogenetic specimens are important in cladoceran taxonomy. Unfortunately, a discussion of polarization of transformation series is still impossible because of our insufficient knowledge of Macrothrix males and the unknown phylogeny of this genus. But current progress allows us to expect that this situation may improve in the near future.

\section{Acknowledgements}

I am grateful to Professor N. N. Smirnov for help at different phases of this investigation, Prof. H. J. Dumont and Dr Korovchinsky for valuable comments, $\operatorname{Dr}$ M. Ja. OrlovaBienkowskaja., Dr A, Y. Sinev and Dr W. Hollwedel for samples with Macrothrix, Dr I. B. Mertsalov for help in preparation of material, Mr V. N. Antropov for technical assistance in the work with SEM. The study was partly supported by the Russian Foundation for Basic Research (grant 06-04-48624), Biodiversity Program of the Presidium of Russian Academy of Sciences (2007, project 1.1.6.) and US NSF grant PEET (project DEB-0331095).

\section{References}

Alonso M. 1996. - Crustacea, Branchiopoda. Consejo Superior de Investigaciones Cientificas, Madrid, 486 p.

Behning A.L. 1941. - Cladocerans of the Caucasus. Gruzmedgiz Publishing, Tbilisi, $384 \mathrm{p}$.

Berg K. 1933. - Note on Macrothrix hirsuticornis Norman \& Brady, with description of the male. Vidensk. Medd. Danske Naturh. Foren. Kobenhavn, 97, 11-24.

Daday E. von. 1901. - Mikroskopische Süsswasserthiere (Édesvizi mikroazkópi Állatok). Zoologische Ergebnisse der dritten asiatiaschen Forschungsreise des Grafen Eugen Zichy, redigiert von Dr. G. Horváth, Budapeat-Leipzig, 2, 375-470.

Dumont H.J. \& Negrea S.V. 2002. - Introduction to the class Branchiopoda. Backhuys Publishers, Leiden, 398 p.

Dumont H.J. \& Silva-Briano M. 1998. - A reclassification of the anomopod families Macrothricidae and Chydoridae, with the creation of a new suborder, the Radopoda (Crustacea: Branchiopoda). Hydrobiologia, 384, 119-149.

Dumont H.J., Silva-Briano M. \& Babu K.K.S. 2002. - A reevaluation of the Macrothrix rosea-triserialis group, with the description of two new species (Crustacea Anomopoda: Macrothricidae). Hydrobiologia, 467, 1-44. 
Flössner D. 1972. - Krebstiere, Crustacea (Kiemen- und Blattfüßer, Branchiopoda, Fischläuse, Branchiura). Gustav Fischer Verlag, Jena, $499 \mathrm{p}$.

Flössner D. 2000. - Die Haplopoda und Cladocera (ohne Bosminidae) Mitteleuropas. Backhuys, Leiden, 428 p.

Frey D.G. 1975. - Subgeneric differentiation within Eurycercus (Cladocera, Chydoridae) and a new species from Northern Sweden. Hydrobiologia, 46, 263-300.

Frey D.G. 1987. - The taxonomy and biogeography of the Cladocera. Hydrobiologia, 145, 5-17.

Garfias-Espejo T., Elías-Gutiérrez M. \& Silva-Briano M. 2007. - On Macrothrix agsensis Dumont, Silva-Briano \& Babu, 2002 (Cladocera: Anomopoda: Macrothricidae), with description of the male and ephippial females, and comments on the distribution of the genus in Mexico. Zootaxa, 1632, 49-60.

Glagolev S.M. 1983. - A structure of ephippium surface in Daphniidae (Crustacea, Cladocera) by the data of scanning electron microscopy. Zool. Zh., 62, 1422-1424. (in Russian)

Goulden C.E. 1968. - The systematics and evolution of the Moinidae. Trans. Amer. Phil. Soc. Philadelphia, n. ser., 58, 1101.

Gurney R. 1909. - On the freshwater Crustacea of Algeria and Tunisia. J. Roy. Micr. Soc., 2, 273-305.

Hudec I. 1983. - Notes on variability of Macrothrix hirsuticornis (Crustacea, Cladocera). Vst. esk. spol. Zool., 47, 27-30.

Ibrasheva S.I. \& Smirnova V.A. 1983. - Cladocerans of Kazakhstan. Mektep Publishing, Alma-Ata, 136 p. (in Russian)

Kim K., Kotov A.A. \& Taylor D.J. 2006. - Hormonal induction of undescribed males resolves cryptic species of cladocerans. Proc. Roy. Soc. London B, 273, 141-147.

Korovchinsky N.M. 2004. - Cladocerans of the order Ctenopoda of the world fauna (morphology, systematics, ecology, biogeography). KMK Press, Moscow, 410 p. (In Russian)

Kotov A.A. 1996. - Morphology and postembryonic development of males and females of Bosmina longispina Leydig (Crustacea, Anomopoda) from a North Iceland population. Hydrobiologia, 341, 187-196.

Kotov A.A. 1999. - Redescription of Macrothrix tripectinata Weisig, 1934 (Anomopoda, Branchiopoda), with a discussion of some features rarely used in the systematics of the genus. Hydrobiologia, 403, 63-80.

Kotov A.A. 2000. - Redescription and assignment of the chydorid Indialona ganapati Petkovski, 1966 (Branchiopoda: Anomopoda: Aloninae) to Indialonini, new tribus. Hydrobiologia, 439, 161178.

Kotov A.A. 2006a. - Adaptations of the Anomopoda (Cladocera) for benthic mode of life. Zool. Zh., 85, 1043-1059.
Kotov A.A. 2006b. - Morphology, systematics and phylogeny of the cladocerans of order Anomopoda (Crustacea, Branchiopoda). Dr. Sci. Thesis. A. N. Severtsov Institute of Ecology and Evolution, Moscow, 503 p.

Kotov A.A. 2007. - Revision of the hirsuticornis-like species of Macrothrix Baird, 1843 (Cladocera: Anomopoda: Macrothricidae) from Subantarctic and temperate regions of the southern hemisphere. J. Nat. Hist., 41, 2569-2620.

Kotov A.A., Garfias-Espejo T. \& Elías-Gutiérrez M. 2004. Separation of two Neotropical species: Macrothrix superaculeata (Smirnov, 1982) versus M. elegans Sars, 1901 (Macrothricidae, Anomopoda, Cladocera). Hydrobiologia, 517, 61-88.

Kownacki A., Wojtusiak J. \& Zurek R. 1976. - Nowie i rzadkie gatunki Rotatoria, Chalocera i Chironomidae (Diptera) dla fauny wodnej Afganistanu. Acta Hydrobiol., 18, 291-304.

Margaritora F.G. 1985. - Cladocera. Edizioni Calderini, Bologna, $399 \mathrm{p}$.

Makrushin A.V. 1985. - The diversity in the structure of ephippium in the Macrothricidae (Crustacea, Cladocera) and the taxonomic status of this family. Zool. Zh., 64, 212-216.

Makrushin A.V. 1991. - On ephippium of Echinisca capensis (Cladocera, Crustacea). Zool.Zh., 70, 136-138.

Manujlova E.F. 1964. - The cladocerans of fauna of the USSR. Opredeliteli po faune SSSR, 88, 1-327. (In Russian)

Negrea S. 1983. Cladocera. Fauna Republicii Socialiste România. Etidura Academiei Repunlicii Socialiste România, Bucureti, 399 p.

Norman A.M. \& Brady G.S. 1867. - A monograph of the British Entomostraca belonging to the families Bosminidae, Macrothricidae and Lynceidae. Natur. Hist. Trans. Northumberland \& Durham, 1, 354-408.

Silva-Briano M. 1998. - A revision of Macrothricid-like anomopods. Ph.D. Thesis. Ghent University, Ghent, 388 p.

Silva-Briano M., Dieu N.Q. \& Dumont H.J. 1999. - Redescription of Macrothrix laticornis (Jurine, 1820), and description of two new species of the M. laticornis-group. Hydrobiologia, 403, 3961.

Smirnov N.N. 1971. - Chydoridae of the world fauna. Fauna SSSR, Rakoobraznie, 1 (2), 1-531. (In Russian)

Smirnov N.N. 1976. - Macrothricidae and Moinidae of the world fauna. Fauna SSSR, Rakoobraznye, 1 (3), 1-237. (In Russian)

Smirnov N.N. 1992. - The Macrothricidae of the world. SPB Academic Publishing, The Hague, 143 p.

Van Damme K. \& Dumont H. 2006. - Sex in a cyclical parthenogen: mating behaviour of Chydorus sphaericus (Crustacea; Branchiopoda; Anomopoda). Freshwater Biology, 51, 2334-2346.

Weisig S. 1934. - Macrothrix tripectinata sp. nov. Tr. Azerbaidzhan. Otd. Zakavkaz. filiala AN SSSR, Zool., 7, 87-90. 
